\title{
Gambaran Rasionalitas Penggunaan Antibiotik berdasarkan Kriteria Gyssens di Bangsal Obstetri dan Ginekologi RSUP Dr. Hasan Sadikin Bandung
}

\author{
Nenny Yoanitha, Firman F. Wirakusumah, M. Rizkar Arev Sukarsa \\ Departemen Obstetri dan Ginekologi Fakultas Kedokteran Universitas Padjadjaran \\ Rumah Sakit Dr. Hasan Sadikin Bandung \\ Korespondensi: Nenny Yoanitha,Email:nennyunpad@gmail.com
}

\begin{abstract}
Abstrak
Tujuan: Penggunaan antibiotik yang tidak rasional terjadi di banyak rumah sakit dan dikaitkan dengan peningkatan jumlah resistensi antibiotik di seluruh dunia. WHO telah menggambarkan bahwa saat ini sedang terjadi "krisis" resistensi antibiotik yang berpotensi menyebabkan musibah secara global. Di Indonesia termasuk RSUP Dr. Hasan Sadikin Bandung data penelitian yang menggambarkan kualitas penggunaan antibiotik masih terbatas.

Metode: Penelitian ini merupakan jenis penelitian deskriptif eksploratif dengan desain cross sectional dilaksanakan di RSUP Dr. Hasan Sadikin Bandung pada periode September-November 2016 pada pasien rawat inap di bangsal Obstetri dan Ginekologi. Rasionalitas penggunaan antibiotik diukur berdasarkan kriteria Gyssens yang mengklasifikasikan kasus penggunaan antibiotik berdasarkan suatu alur memuat indikasi, jenis antibiotik, dosis, rute, interval, dan waktu pemberiannya.

Hasil: Dari 150 kasus mayoritas merupakan kasus obstetri (62,7\%) dengan kelompok umur terbanyak antara 21-35 tahun (73,3\%). Berdasarkan kriteria gyssens didapatkan terbanyak adalah kategori V (40,3\%), sedangkan kategori 0 (antibiotik rasional) didapatkan sebanyak (22\%).

Kesimpulan: Penggunaan antibiotik yang tidak rasional berdasarkan kriteria Gyssens masih tinggi ditemukan di bangsal Kandungan dan Kebidanan
\end{abstract}

Kata kunci : Antibiotik, kualitas penggunaan antibiotik, kriteria gyssens

\section{The Rationality of Antibiotic use based on Gyssens Criteria at Obstetric and Gynecology Ward Dr. Hasan Sadikin General Hospital}

\begin{abstract}
Objective: The use of irrational antibiotics occurs in many hospitals and is associated with an increase of antibiotic resistance worldwide. WHO has described that there is currently a "crisis" of antibiotic resistance that has the potential to cause a global disaster. In Indonesia, including dr. Hasan Sadikin Hospital research data describing the quality of antibiotic use is still limited.

Method: This study is a descriptive explorative research with cross sectional design that was conducted in dr. Hasan Sadikin Hospital on September until November 2016 with the sample was all inpatient that trated in the Obstetric and Gynecology ward.. The rationality of antibiotic use is measured by the Gyssens criteria that classify cases of antibiotic use based on a path containing indications, type of antibiotics, doses, routes, intervals, and time of administration.

Result: Of the 150 cases the majority were obstetric cases (62.7\%) with the most age group between 21-35 years (73.3\%). Based on the criteria gyssens obtained the most is category V (40.3\%), while category 0 (rational antibiotics) obtained as much (22\%).

Conclusion: The use of irrational antibiotics based on the Gyssens criterion is still high in the Obstetric and Gynecology ward
\end{abstract}

Key words: Antibiotics, quality of antibiotic use, criteria gyssens 


\section{Pendahuluan}

Puluhan tahun sejak pertama kali antibiotik ditemukan, saat ini infeksi bakteri kembali menjadi ancaman di seluruh dunia. Beberapa bakteri resisten saat ini muncul dengan cepat, terjadi di berbagai negara maju maupun berkembang yang dapat membahayakan efektifitas kerja antibiotik secara luas. ${ }^{1,2}$

Berdasarkan penelitian di Amerika Serikat, setiap tahun sedikitnya 2 juta orang menderita infeksi serius yang telah resisten terhadap 1 atau lebih antibiotik dan setidaknya 23.000 orang meninggal sebagai akibat langsung infeksi bakteri yang resisten terhadap antibiotika. ${ }^{2,3}$ Penelitian AMRIN (Antimicrobial resistance in Indonesia) tahun 2008 mendapatkan $32,1 \%$ pasien terinfeksi bakteri $S$. aureus yang resisten antibiotik. Pada penelitian terhadap pada 4000 pasien terinfeksi E.coli didapatkan resistensi gentamisin 18\%, sefotaksim $13 \%$, dan siprofloksasin $22 \%$. Resistensi terhadap ampisilin 43\%, trimethoprim sulfametoksasol (kotrimokzasol) 35\%, dan kloramfenikol 21\%.,5 Pada tahun 2015 penelitian di RSUP Dr. Hasan Sadikin ditemukan bahwa sebanyak $15,7 \%$ bakteri Klebsiella pneumonia telah resisten terhadap karbapenem. ${ }^{6}$

World Health Organization (WHO) menyebutkan bahwa kejadian resistensi antibiotik berlangsung secara alamiah, namun penggunaan antibiotik yang tidak tepat dapat memicu munculnya resistensi antibiotik. ${ }^{7}$ Beberapa studi telah menunjukkan bahwa penggunaan antibiotik dengan indikasi pengobatan, pilihan agen, atau durasi terapi antibiotik yang tidak tepat terjadi antara $30 \%$ sampai 50\% kasus di seluruh dunia. Penelitian di AS melaporkan bahwa hanya $7,6 \%$ pasien rawat inap dengan CAP (CommunityAcquired Pneumonia) yang benar-benar patogen. ${ }^{8}$ Kementerian Kesehatan RI telah menyampaikan penelitian yang dilakukan oleh tim AMRIN 2008 yang menunjukkan bahwa sebanyak $83 \%$ pasien mendapat terapi antibiotik dengan penggunaan antibiotik yang tidak rasional sebanyak $60 \% .^{5}$ Penelitian di RSUP Dr. Hasan Sadikin tahun 2008 menemukan sebanyak $26 \%$ pasien mendapat antibiotik tidak tepat durasi pemberiannya, $25 \%$ tidak tepat dosis, dan 3,8\% pasien diberikan antibiotik yang sebenarnya telah resisten. ${ }^{6}$

Penggunaan antibiotik yang tidak rasional merupakan faktor utama yang menyebabkan resistensi antibiotik di seluruh dunia. Efektivitas kerja antibiotik telah menurun karena penggunaan yang melebihi dosis terapeutik atau penggunaan yang tidak tepat karena infeksi non bakterial, seperti influenza, yang sebenarnya tidak memerlukan antibiotik. Penggunaan antibiotik yang salah inilah yang menyebabkan bakteri menjadi resisten. ${ }^{3}$

Hal ini menjadi problem utama dalam perawatan pasien. Pengobatan menjadi tidak efektif, peningkatan morbiditas maupun mortalitas pasien, perpanjangan waktu rawat, dan meningkatnya biaya perawatan kesehatan. ${ }^{2,9}$ American College of Obstetricians and Gynecologists (ACOG) sebenarnya telah merekomendasikan pemberian antibiotik pada berbagai jenis tindakan dan kasus di bidang Obgyn, diantaranya penggunaan antibiotik golongan sefalosporin generasi pertama sebagai antibiotik profilaksis kasus pembedahan baik kasus obstetri maupun ginekologi, disebutkan pula tidak diperlukan antibiotik profilaksis pada persalinan pervaginam tanpa komplikasi. ${ }^{710}$ Pada tahun 1991 Gyssens telah membuat suatu kriteria untuk penilaian kualitas antibiotik ${ }^{11,12}$ Kriteria Gyssens saat ini sudah mulai dipakai luas di berbagai institusi dalam melakukan penelitian untuk menilai kualitas penggunaan antibiotik. Kriteria Gyssens untuk penilaian kualitas penggunaan antibiotik dapat dilihat pada Tabel 1. 
Metode

Jenis penelitian ini adalah deskriptif eksploratif dengan desain penelitian cross sectional. Penelitian ini akan menilai kualitas penggunaan antibiotik berdasarkan kriteria gyssens dengan variabel bebas jenis antibiotik, indikasi pemberian, dosis, interval, rute, durasi pemberian antibiotik, dan karakteristik pasien yaotu usia. Nariabel tergantungnya adalah Kualitas penggunaan antibiotic menurut Gyssens. Sebanyak 150 pasien dipilih secara acak sederhana yaitu pasien yang dirawat inap di bangsal obstetri dan ginekologi RSUP Dr. Hasan Sadikin Bandung periode September-November 2016. Sumber data diambil dari data sekunder yaitu rekam medis pasien. Data yang sudah diperoleh selanjutnya disusun dan ditabulasi serta disajikan dalam bentuk tabel. Adapun kriteria kualitas penggunaan antibiotik menurut Gyssens dapat dilihat pada Tabel 1.

\section{Hasil}

Penelitian telah dilakukan pada 150 pasien rawat inap. Didapatkan bahwa karakterisitik usia pasien terbanyak pada kelompok 21-35 tahun yaitu 110 pasien $(73,3 \%)$ dengan jenis kasus terbanyak yang menggunakan antibiotik adalah kasus obstetri yaitu 84 kasus (56\%). Jenis antibiotik terbanyak yang digunakan adalah cefadroxil yaitu 111 (47\%) dengan indikasi pemberian antibiotik yang terbanyak sebagai terapi empiris yaitu $184 \quad(77 \%)$ kasus, dan rute pemberian terbanyak secara intravena yaitu 122 (51,6\%). Berdasarkan kategori Gyssens yang terbanyak adalah kategori V yaitu 95 (40,3\%) kasus, sedangkan kategori 0 hanya 52 (23\%) kasus.

Tabel 1 Kriteria Kualitas Penggunaan Antibiotik menurut Kriteria Gyssens ${ }^{13}$

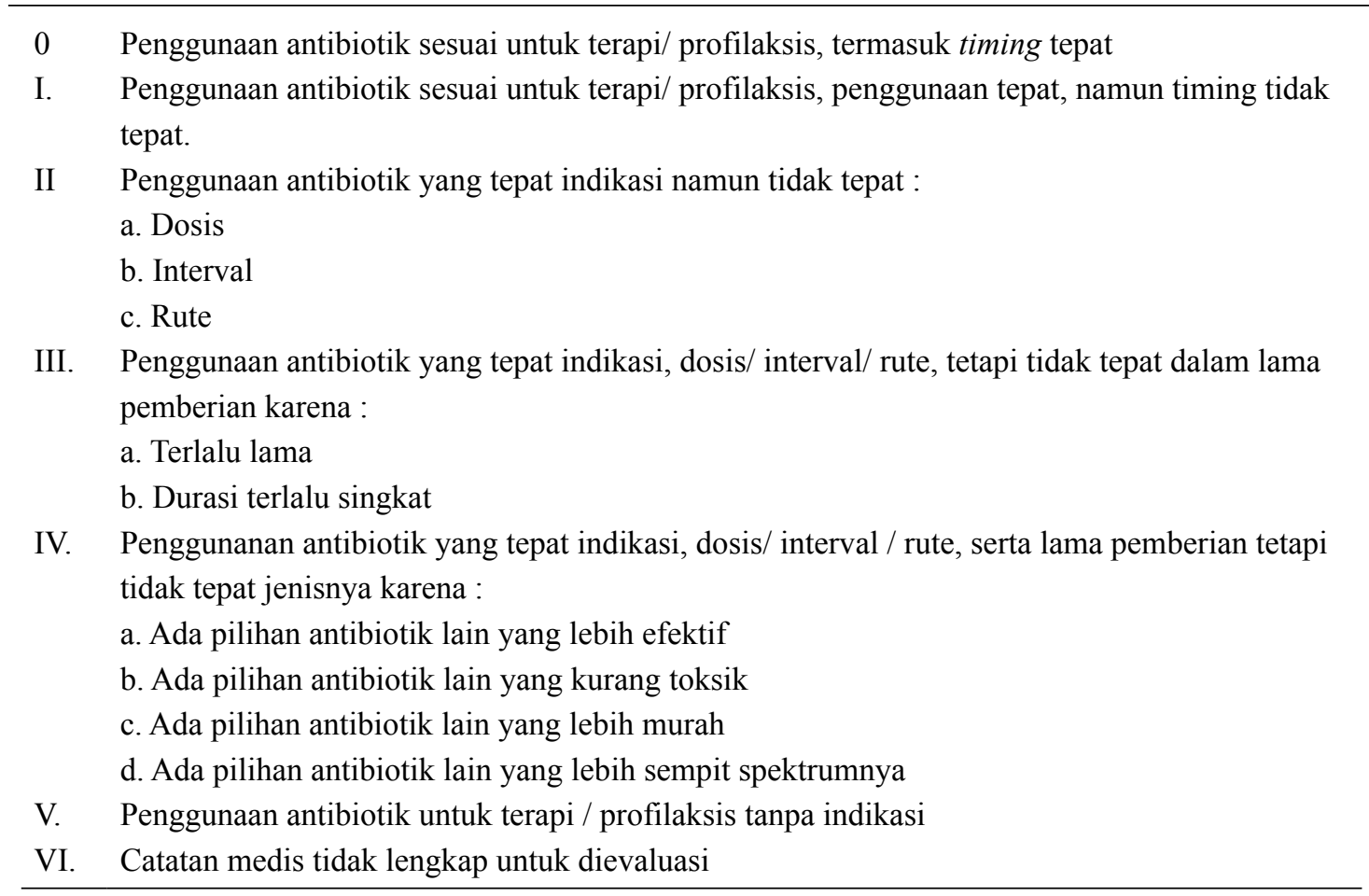


Tabel 2 Karakteristik Subjek Penelitian

\begin{tabular}{lc}
\hline \multicolumn{1}{c}{ Variabel } & $\mathbf{N}=\mathbf{1 5 0}$ \\
\hline Usia & \\
$<16$ tahun & $2(1,4 \%)$ \\
$16-20$ tahun & $6(4 \%)$ \\
$21-35$ tahun & $110(73,3 \%)$ \\
$>35$ tahun & $32(21,3 \%)$ \\
\hline
\end{tabular}

Tabel 3 Gambaran Penggunaan Antibiotik Berdasarkan Jenis Kasus

\begin{tabular}{lc}
\hline \multicolumn{1}{c}{ Variabel } & N=150 \\
\hline Kasus & \\
Obstetri : & $94(62,7 \%)$ \\
Menggunakan antibiotik & $84(56 \%)$ \\
Tidak & $10(6,7 \%)$ \\
Ginekologi : & $56(37,3 \%)$ \\
Menggunakan antibiotik & $31(20,6 \%)$ \\
Tidak & $25(16,7 \%)$ \\
\hline
\end{tabular}

Tabel 4 Gambaran Penggunaan Antibiotik Berdasarkan Jenis Antibiotik, Indikasi Terapi, dan Rute Pemberian

\begin{tabular}{lc}
\hline \multicolumn{1}{c}{ Variabel } & $\mathbf{N}=\mathbf{2 3 6}$ \\
\hline Nama Antibiotik & \\
Amoxicilin & $2(0,8 \%)$ \\
Ampicilin & $1(0,5 \%)$ \\
Cefadroxil & $111(47 \%)$ \\
Cefazoline & $52(22 \%)$ \\
Cefotaxime & $4(1,7 \%)$ \\
Ceftriaxone & $61(25,8 \%)$ \\
Metronidazole & $4(1,7 \%)$ \\
Cefixime & $1(0,5 \%)$ \\
Indikasi & \\
Empiris & $184(77.0 \%)$ \\
Profilaksis & $52(23.0 \%)$ \\
Rute Pemberian & \\
IV & $122(51,6 \%)$ \\
Oral & $114(48,4 \%)$ \\
\hline
\end{tabular}

Tabel 5 Gambaran Penggunaan Antibiotik Berdasarkan Kategori Gyssens

\begin{tabular}{lc}
\hline \multicolumn{1}{r}{ Variabel } & N=236 \\
\hline Kategori Gyssens & \\
VI & $0(0.0 \%)$ \\
V & $95(40.3 \%)$ \\
IV & $89(37.7 \%)$ \\
IIIA & $0(0.0 \%)$ \\
III B & $0(0.0 \%)$ \\
II & $0(0.0 \%)$ \\
I & $0(0.0 \%)$ \\
0 & $52(22 \%)$ \\
\hline
\end{tabular}

\section{Pembahasan}

Dalam penelitian ini menunjukan jenis kasus terbanyak adalah kasus obstetri dan hampir semua pasien tersebut diberikan terapi antibiotik. Ditemukan bahwa berdasarkan kategori gyssens pemberian antibiotik terbanyak adalah kategori IV dan $\mathrm{V}$ yang artinya pemberian antibiotik tidak rasional karena tidak ada indikasi, terdapat pilihan antibiotik lain yang lebih efektif, lebih murah, atau kurang toksik. Antibiotik yang paling sering digunakan adalah cefadroxil yang diberikan sebagai terapi empiris pasca persalinan spontan dan ceftriaxon pada kasus pasca seksio sesarea. Pada penelitian ini ditemukan penggunaan cefadroxil yang kurang tepat dan tidak jelas indikasi pemberiannya karena secara rutin diberikan pada kasus-kasus partus spontan tanpa faktor risiko infeksi atau tanda-tanda infeksi. Demikian pula dengan pemberian ceftriaxone yang tidak rasional karena diberikan secara rutin pasca operasi seksio sesaria atau kasus ginek-onkologi padahal tidak ditemukan tanda-tanda ke arah infeksi pasca operasi.

Kategori 0 (antibiotik rasional) didapatkan hanya sebanyak 52 (22\%). Angka ini didapatkan karena penggunaan antibiotik sefalosporin generasi I (cefazolin) secara intravena yang digunakan sebagai terapi 
profilaksis sebelum prosedur pembedahan baik kasus obstetri maupun ginekologi. Pemberian cefazoline sebagai antibiotik profilaksis prabedah telah direkomendasikan oleh ACOG (American College of Obstetricians and Gynecologists) karena telah terbukti menurunkan angka kejadian infeksi pasca bedah.

Rendahnya angka penggunaan antibiotik rasional yang ditemukan pada penelitian ini mungkin disebabkan oleh beberapa faktor, antara lain kurangnya pengetahuan klinisi tentang penggunaan obat antibiotik termasuk indikasi, pemilihan obat yang efektif, dan juga tidak adanya prosedur tetap penggunaan antibiotik di bagian Obstetri dan Ginekologi RSUP Dr. Hasan Sadikin Bandung.

\section{Saran}

Penggunaan antibiotik yang tidak rasional cukup tinggi ditemukan di RSUP Dr. Hasan Sadikin. Diperlukan komitmen dari berbagai pihak untuk perbaikan hal tersebut, termasuk diantaranya peningkatan pengetahuan klinisi mengenaipenggunaan antibiotik yangrasional melalui pelatihan dan sosialisasi, pembuatan prosedur tetap penggunaan antibiotik, ditunjang dengan kebijakan manajemen RS, Tim PPRA, Komite Medik, dan Farmasi yang tegas dalam pelaksanaan, pengawasan dan evaluasi pemberian antibiotik rasional yang terintegrasi dan berkesinambungan di RSUP Dr. Hasan Sadikin Bandung.

\section{Daftar Pustaka}

1. Burroughs T, Najafi M, Lemon SM, Knobler SL. The Resistance Phenomenon in Microbes and Infectious Disease Vectors: Implications for Human Health and Strategies for Containment. Microbe Resistance. Washington DC: National Academies Press; 2003. p. 44-78.

2. Ventola CL. The Antibiotic Resistance Crisis: Causes and Threats. Pharmacy and Therapeutics. 2015;40(4):277.

3. CDC. Antibiotic Resistance Threats in the United States, 2013: Centres for Disease Control and Prevention, US Department of Health and Human Services; 2013. Diakses dari: https://www.cdc.gov/ drugresistance/threat-report-2013/index. html.

4. Dertarani V. Evaluasi Penggunaan Antibiotik Berdasarkan Kriteria Gyssens di Bagian Ilmu Bedah RSUP Kariadi tahun 2009. Semarang. Diakses dari: http://eprints.undip.ac.id/8084/1/Vindi_ Dertarani.pdf.

5. Lestari ES, Severin JA. Antimicrobial Resistance in Indonesia: Prevalence, Determinants and Genetic Basis. Rotterdam: Erasmus University Rotterdam; 2009.

6. Wahyudi B, Wirakusumah FF, Shahib MN, Setiawati EP, Parwati I. Relationship between Intrinsic and Extrinsic Factors in Klebsiella Pneumoniae Bacterium Nosocomial Infectional Patients with Carbapenem Resistance by New Delhi Metallo-B-Lactamase 1 in Medical and Surgical Cases. IJDR. 2015;5(12):626670.

7. ACOG. Antibiotic Prophylaxis for Gynecologic Procedures. American College of Obstetricians Gynecologists Practice Bulletin (January). 2001;23:109.

8. Bartlett JG, Gilbert DN, Spellberg B. Seven Ways to Preserve the Miracle of Antibiotics. Clin Infect Dis. 2013;56(10):1445-50.

9. WHO. Global Action Plan On Antimicrobial Resistance Switzerland: World Health Organization; 2015. Diakses dari: http://www.who.int/antimicrobialresistance/global-action-plan/en/.

10. ACOG. Use of Prophylactic Antibiotics in Labor and Delivery: Practice Bulletin No. 120. Obstet Gynecol. 2011;117(6):1472.

11. Van der Meer J, Gyssens I. Quality of Antimicrobial Drug Prescription 
in Hospital. Clin Microbiol Infect. 2001;7:12-5.

12. Gyssens IC. Quality Measures of Antimicrobial Drug Use. Int J Antimicrob Agents. 2001;17(1):9-19.

13. Gelband H, Molly Miller P, Pant S, Gandra
S, Levinson J, Barter D, et al. The State of the World's Antibiotics 2015. Wound healing southern africa. 2015;8(2):30-4. 